\title{
Distinct gene expression profiles in ovarian cancer linked to Lynch syndrome
}

\author{
Jenny-Maria Jönsson · Katarina Bartuma $\cdot$ Mev Dominguez-Valentin • \\ Katja Harbst - Zohreh Ketabi · Susanne Malander • Mats Jönsson • \\ Ana Carneiro · Anna Måsbäck · Göran Jönsson · Mef Nilbert
}

Published online: 22 May 2014

(C) The Author(s) 2014. This article is published with open access at Springerlink.com

\begin{abstract}
Ovarian cancer linked to Lynch syndrome represents a rare subset that typically presents at young age as early-stage tumors with an overrepresentation of endometrioid and clear cell histologies. We investigated the molecular profiles of Lynch syndrome-associated and sporadic ovarian cancer with the aim to identify key discriminators and central tumorigenic mechanisms in hereditary ovarian cancer. Global gene expression profiling using whole-genome c-DNA-mediated Annealing, Selection, extension, and Ligation was applied to 48 histopathologically matched Lynch syndrome-associated and sporadic ovarian cancers. Lynch syndrome-associated and sporadic ovarian cancers differed by 349 significantly
\end{abstract}

Jenny-Maria Jönsson and Katarina Bartuma have contributed equally to this work.

Electronic supplementary material The online version of this article (doi:10.1007/s10689-014-9728-1) contains supplementary material, which is available to authorized users.

J.-M. Jönsson ( $₫)$ · K. Bartuma · M. Dominguez-Valentin · K. Harbst · S. Malander · M. Jönsson - A. Carneiro · G. Jönsson · M. Nilbert

Division of Oncology, Department of Clinical Sciences, Skane University Hospital, Lund University, 22185 Lund, Sweden

e-mail: jenny-maria.jonsson@med.lu.se

K. Harbst · G. Jönsson

CREATE Health Strategic Center for Translational Cancer

Research, Lund University, Lund, Sweden

Z. Ketabi $\cdot$ M. Nilbert

HNPCC-register, Clinical Research Centre, Hvidovre Hospital, Copenhagen University, Hvidovre, Denmark

A. Måsbäck

Department of Pathology, Institute of Laboratory Sciences,

Skane University Hospital, Lund, Sweden deregulated genes, including PTPRH, BIRC3, SHH and TNFRSF6B. The genes involved were predominantly linked to cell growth, proliferation, and cell-to-cell signaling and interaction. When stratified for histologic subtype, hierarchical clustering confirmed distinct differences related to heredity in the endometrioid and serous subtypes. Furthermore, separate clustering was achieved in an independent, publically available data set. The distinct genetic signatures in Lynch syndrome-associated and sporadic ovarian cancers point to alternative preferred tumorigenic routes and suggest that genetic discriminators may be relevant for molecular diagnostics and targeted therapeutics.

Keywords HNPCC - Gene expression profiles - DASL · Candidate genes

\section{Introduction}

Lynch syndrome is estimated to cause $2-4 \%$ of ovarian cancer. Recognition of these cases is challenging, and many of the 9,000 ovarian cancers annually estimated to develop as part of Lynch syndrome probably escape detection. Whereas sporadic ovarian cancer and hereditary cancer caused by BRCA1 and BRCA2 gene mutations develop at a mean age of $65-70$ years, typically show serous histopathology and present at advanced tumor stages $[1,2]$, ovarian cancer linked to Lynch syndrome typically develops at a mean age of 45 years as early-stage tumors of the endometrioid and clear cell histologic subtypes [2-7]. Lynch syndrome is caused by germline mutations in the mismatch-repair (MMR) genes MLH1, MSH2, MSH6 and $P M S 2$. Carriers of disease-predisposing mutations are estimated to be at 7-12\% life-time risk for ovarian cancer, at $50-80 \%$ risk for colorectal cancer and at $40-60 \%$ risk 
for endometrial cancer $[5,8,9]$. Recognition of ovarian cancers linked to Lynch syndrome tumors is important since family members at risk can be offered surveillance and/or prophylactic measures that reduce morbidity and mortality, not least from the more commonly occurring colorectal cancers.

In ovarian cancer, the different histopathologic subtypes have been suggested to constitute separate disease entities with differences related to biological features, treatment response and prognosis [10, 11]. A dualistic model for the development of ovarian cancer has been proposed. Highgrade serous, high-grade endometrioid and undifferentiated carcinomas are thought to develop de novo, most likely from serous tubal intraepithelial carcinomas, whereas lowgrade serous, low-grade endometrioid, mucinous and clear cell carcinomas show stepwise tumor development from precursors such as adenofibromas, borderline tumors and endometriosis [12, 13]. In line with this model, gene expression profiles differ between the various histologic subtypes as well as between invasive tumors and tumors of low-malignant potential $[14,15]$. In colorectal cancer and in endometrial cancer, the MMR defective tumors are characterized by few gross genomic alterations and upregulation of e.g. immune-regulatory genes. With the aim to identify gene expression profiles and genetic discriminators linked to MMR defective ovarian tumors, we applied global gene expression analysis to Lynch syndrome-associated and sporadic cancers.

\section{Materials and methods}

\section{Tumor samples}

We collected paraffin-embedded tumor tissue from Swedish and Danish Lynch syndrome mutation carriers and matched these tumors to sporadic ovarian cancers to correct for differences related to histopathology [15]. Histopathologic subtype and grade were determined according to Silverberg and to the WHO guidelines [16-18]. Hematoxylin \& Eosin stained slides were reviewed by a gynecologic pathologist (AM) to verify histopathologic subtype and tumor grade. In total, 24 Lynch syndrome tumors from individuals with germline mutations in MLHI $(\mathrm{n}=1), M S H 2(\mathrm{n}=13)$ or MSH6 $(\mathrm{n}=10)$ and an associated loss of immunohistochemical MMR protein expression were included along with 24 sporadic ovarian cancers in which heredity had been excluded based on family history, normal MMR protein staining and normal results from BRCAl and BRCA2 mutation analysis $[1,3,19]$. Clinical characteristics are outlined in Table 1 and detailed data are provided in online resource 1 . Tumor tissue for immunohistochemical assessment of target genes was available from 46 tumors. Ethical approval for the
Table 1 Clinical characteristics of matched Lynch syndrome-associated and sporadic ovarian tumors in this study

$\begin{array}{ll}\text { Lynch syndrome tumors } & \text { Sporadic tumors } \\ \mathrm{n}=24 & \mathrm{n}=24\end{array}$

Age at diagnosis

Median years (range) $47.0(30-71) \quad 57.0(34-78)$

Histologic subtype (\%)

$\begin{array}{lll}\text { Serous } & 10(42) & 10(42) \\ \text { Mucinous } & 0 & 0 \\ \text { Endometroid } & 7(29) & 7(29) \\ \text { Clear cell } & 7(29) & 7(29) \\ \text { Grade (\%) } & & \\ 1 \text { (well) } & 9(37.5) & 11(46) \\ 2 & 10(42) & 6(25) \\ 3 \text { (poor) } & 5(20.5) & 6(25) \\ 2 / 3 & 0 & 1(4) \\ \text { FIGO stage (\%) } & & 11(46) \\ \text { I } & 13(54) & 5(21) \\ \text { II } & 2(8.5) & 7(29) \\ \text { III } & 4(16.5) & 0 \\ \text { IV } & 0 & 1(4) \\ \text { Unknown } & 5(21) & 11.0(10-28) \\ \text { Age of FFPE tissue } & & \\ \text { Median years (range) } & 20.5(3-54) & \end{array}$

study was granted from the ethics committee in Region Hovedstaden, Denmark and from the Lund University ethics committee, Sweden.

RNA extraction and gene expression analysis

3-5 Tissue 10- $\mu \mathrm{m}$ sections were selected from non-necrotic tumor areas with $>70 \%$ tumor cell content. RNA was extracted using the High Pure RNA Paraffin Kit (Roche, Castle Hill, Australia) and RNA concentrations were determined using a NanoDrop Spectrophotometer (NanoDrop Technologies, Wilmington, DE) requiring $300 \mathrm{ng}$ of RNA with 260/280 ratios $>1.8$. Gene expression analyses were performed at the SCIBLU Genomics Centre, Lund University, Sweden. The cDNA mediated Annealing, Selection, extension and Ligation (WG-DASL) assay (Illumina Inc, San Diego, CA) containing 24,526 probes, which represent 18,626 unique genes, was used for whole genome expression analysis. The samples were randomized on the chips and were profiled following the manufacturer's instructions. BeadChips were then scanned on a BeadArray $^{\mathrm{TM}}$ Reader using BeadScan software (v4.2), during which fluorescence intensities were read and images extracted. 
Data analysis

A raw average signal intensity $>250$ and $>8,000$ detected genes was required for further analysis of the samples. All 48 matched tumors met these criteria. The expression data were uploaded in the GenomeStudio software (Illumina Inc), quantile normalized and a presence filter of $80 \%$ was applied to the probes across all samples with a detection $p$ value of $<0.01$, leaving 12,897 probes for further analysis. The data were imported into $\mathrm{MeV}$ 4.6.02 software [20] and were $\log 2$ transformed and mean centered across assays. Unsupervised clustering using complete linkage hierarchical cluster analysis and Pearson correlation as similarity metric was performed. Two-class unpaired significance analysis of microarrays (SAM), including a permutation test using 100 permutations, was used to identify differentially expressed genes between the Lynch syndrome-associated and sporadic tumors at a false discovery rate (FDR) <0.01 [21]. Gene ontology analyses were generated through the use of Ingenuity Pathway Analysis (IPA; www.ingenuity.com). The data are available in NCBI's Gene Expression Omnibus [22] through GEO Series accession number GSE37394. Technical reproducibility was granted through inclusion of duplicate samples, which demonstrated a mean correlation of 0.98 (range $0.90-0.99$ ) and a mean $r^{2}$ value of 0.96 (range 0.81-0.99). In order to ensure data robustness, data analysis was independently performed using alternative parameters and stricter criteria, i.e. cubic spline normalization and RefSeq features present in $70 \%$ of the samples $(p=0.01)$. This approach left 3,380 probes that were further analyzed as described above (including cluster analyses, permutation test and leave-one-out test, followed by gene ontology analyses).

Validation in an independent, publically available data set

The Lynch syndrome gene signature was validated using an independent, publically available data set consisting of 2,844 genes, mainly based on high-grade serous and endometrioid ovarian cancers [14]. The data were imported into $\mathrm{MeV} v 4, \log 2$ transformed and the probes were mean centred across assays. Unsupervised hierarchical clustering was performed as described above.

\section{Immunohistochemical staining}

Immunohistochemical staining for key target genes was performed on fresh $3-\mu \mathrm{m}$ sections from formalin-fixed, paraffin-embedded tumor tissue and the slides were mounted on ChemMate Capillary Gap Microscope Slides (DAKO A/S, Glostrup, Denmark). The sections were pretreated in PT Link (mTOR, PTEN) and Proteinase K (EGFR) according to the manufacturer's instructions and stained in an automated immunostainer (TechMate 500 Plus, DAKO) with application of the DAKO EnVision ${ }^{\mathrm{TM}}$ Systems (DAKO) for visualization. The antibodies used included phosphorylated mTOR (p-mTOR, clone 49F, diluted 1:80, Cell Signaling Technology, Danvers, MA), PTEN (clone 6H2.1, diluted 1:100, DAKO) and EGFR (clone E30, diluted 1:25, DAKO). Evaluations were blinded to the hereditary status as well as to gene expression data and were performed independently by KB and JMJ. The p-mTOR stains were dichotomized as positive/negative, with any cytoplasmic p-mTOR staining considered positive. PTEN was evaluated as negative (no staining or weaker staining in the tumor cells compared to the surrounding tissues) or positive (equal or stronger cytoplasmic staining in tumor cells compared to surrounding tissues). EGFR staining was evaluated according to staining intensity (no, weak, moderate, or strong staining) and the percentage of stained tumor cells; tumors with $>25 \%$ of the cells moderately or intensely stained for EGFR were classified as positive [23-25]. MMR protein staining is outlined in Ketabi et al. [19].

\section{Statistical analysis}

The Pearson correlation test was used to analyze gene expression data in duplicate samples. Fischer's exact test was used to assess correlations between the immunohistochemical stainings. The analyses were conducted using the R software and SPSS software respectively (IBM SPSS version 19). $p$ Values $<0.05$ were considered significant.

\section{Results}

Unsupervised and supervised hierarchical cluster analysis in the matched dataset of 24 Lynch syndrome-associated and 24 sporadic tumors identified two major clusters related to hereditary status (online resource 2 and Fig. 1, respectively). SAM analysis identified 349 genes that were significantly deregulated between the Lynch syndrome tumors and the sporadic ovarian tumors (FDR $<0.01$ ) (online resource 3). The top up-regulated genes in Lynch syndrome-associated tumors included e.g. PTPRH, BIRC3, $S H H$ and TNFRSF6B. Enriched gene ontology processes were related to cellular growth and proliferation, cell death, and cell-to-cell signaling and interaction (Table 2). In sporadic ovarian cancers, SAM analysis identified up-regulation of e.g. $\mathrm{SHCl}$, which is involved in protein tyrosine kinase activity, and FSCN1, which is related to protein binding (online resource 3 ). 


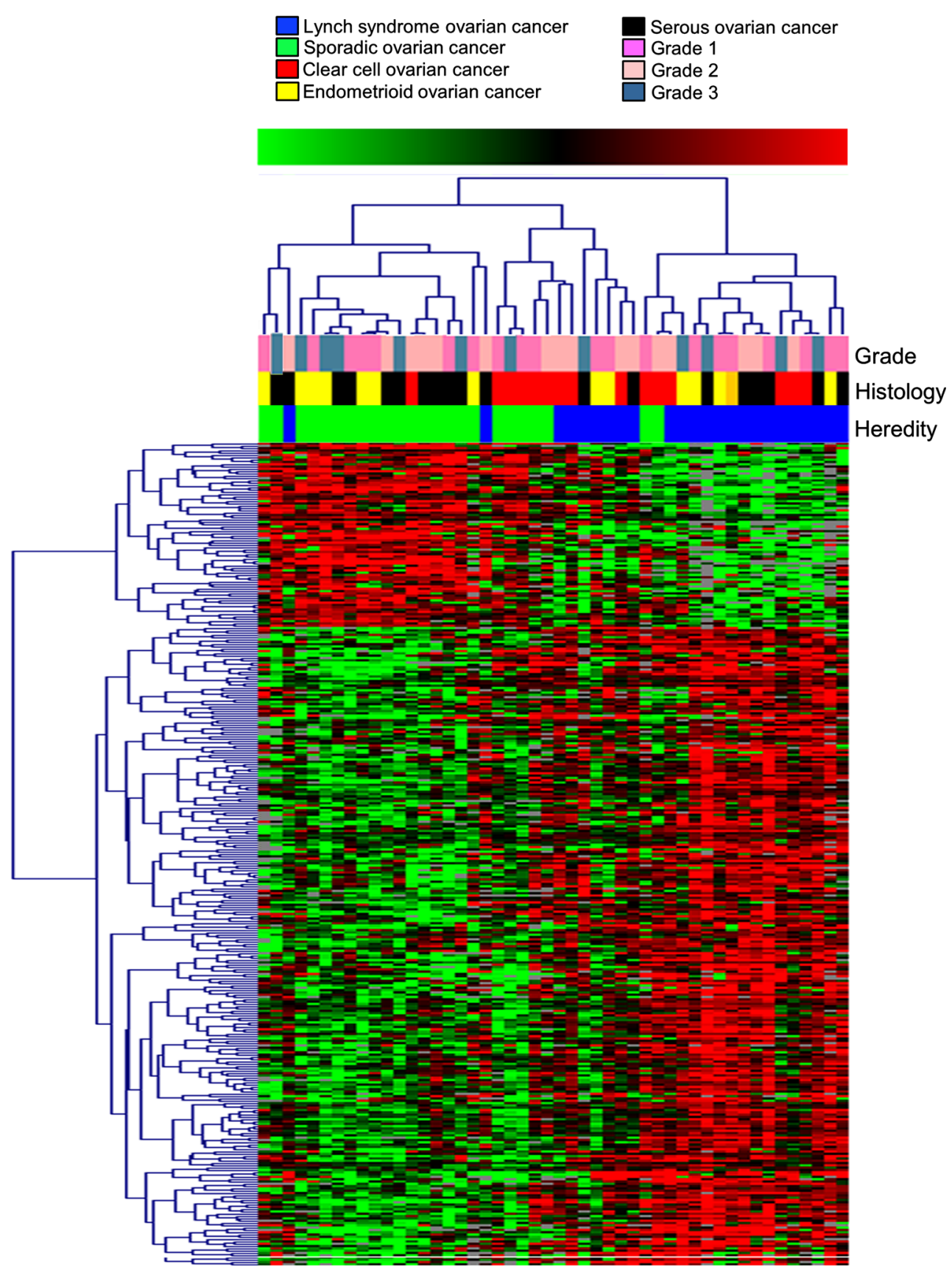

Fig. 1 SAM analysis of differentially expressed genes $(n=349)$ in Lynch syndrome-associated and sporadic ovarian cancers at FDR $<0.01$. Clustering was done using the TmeV application with the Pearson correlation distance metric for complete linkage

Table 2 Enriched gene ontology processes in Lynch syndromeassociated ovarian cancer

\begin{tabular}{lc}
\hline Gene ontology processes & $p$ value \\
\hline Cell growth and proliferation & 0.000010 \\
Cell death and survival & 0.000023 \\
Cellular development & 0.000050 \\
Cellular function and maintenance & 0.000050 \\
Cell-to-cell signaling and interaction & 0.000083
\end{tabular}

Independent analysis using cubic spline normalization and requiring presence of RefSeq features in $70 \%$ of the samples left 3,380 probes for analysis. Data stability was demonstrated using unsupervised hierarchical clustering, which resulted in identical clustering between Lynch syndrome tumors and sporadic tumors as in the original data set, and leave-one-out analysis, which correctly classified $79 \%$ of the hereditary tumor samples and $62.5 \%$ of the sporadic tumor samples. Based on these data, unsupervised 
Fig. 2 Unsupervised

hierarchical cluster analysis of Lynch syndrome-associated and sporadic ovarian cancers in the separate histopathological subtypes. The analyses were performed using a 3,380 probe data set

\section{Lynch syndrome ovarian cancer \\ Sporadic ovarian cancer}
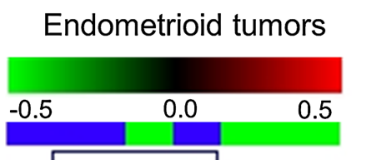
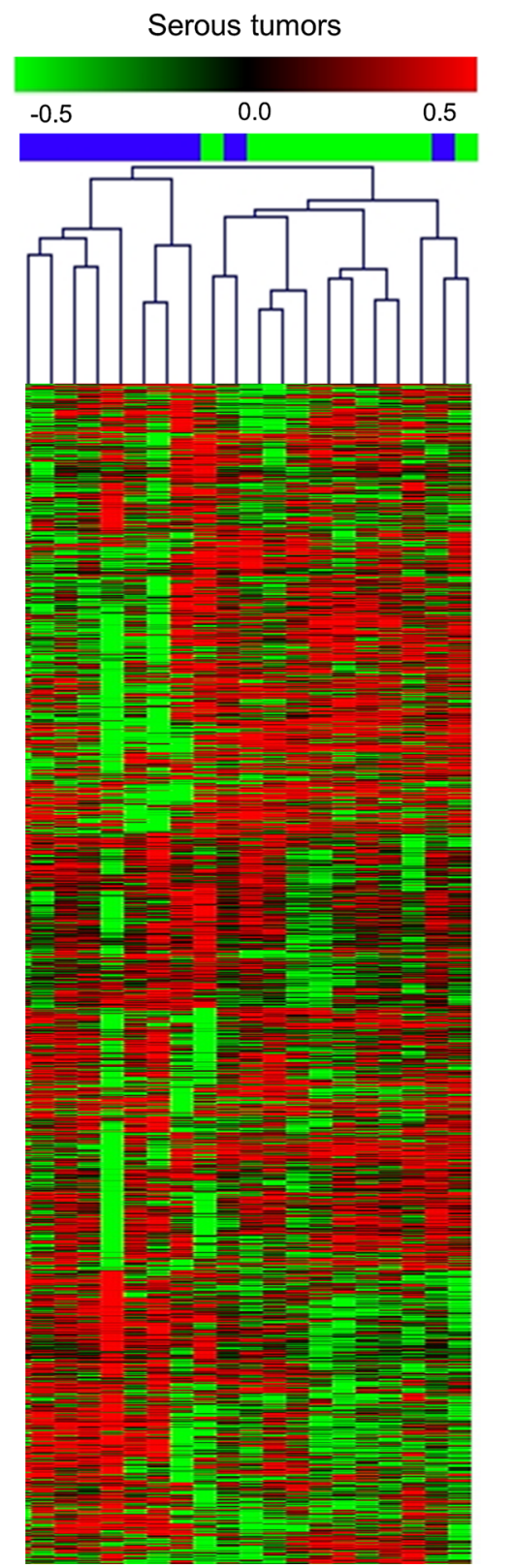

Clear cell tumors

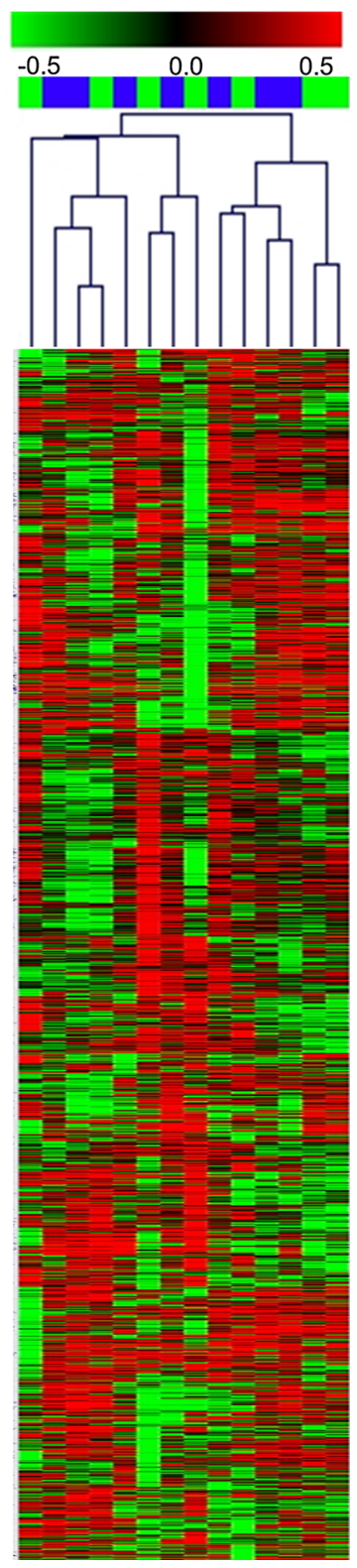

hierarchical clustering was performed in the different histopathologic subtypes and identified clustering related to heredity in endometrioid and serous cancers, but not in clear cell cancers (Fig. 2). SAM analysis in the former subgroups identified 17 and 33 differentially expressed genes, respectively, between Lynch syndrome-associated and sporadic tumors (FDR $<0.01)$ (online resource 4).

Application of a publically available 2,844 gene signature to our data identified 1,346 genes that were shared between the data sets [14]. Unsupervised hierarchical cluster analysis based on these 1,346 genes resulted in two main clusters with 20/24 Lynch syndrome tumors in one cluster, whereas the sporadic tumors were divided between the clusters (Fig. 3).

Immunohistochemical stainings demonstrated positivity for p-mTOR in 14/23 Lynch syndrome tumors and in 12/23 sporadic tumors ( $p=0.767)$, positive staining for EGFR in $7 / 23$ Lynch tumors and in 2/22 sporadic tumors $(p=0.135)$ and loss of PTEN in 17/23 Lynch syndrome tumors compared to in $14 / 23$ sporadic tumors $(p=0.530)$ (Fig. 4$)$. 
Lynch syndrome ovarian cancer Sporadic ovarian cancer

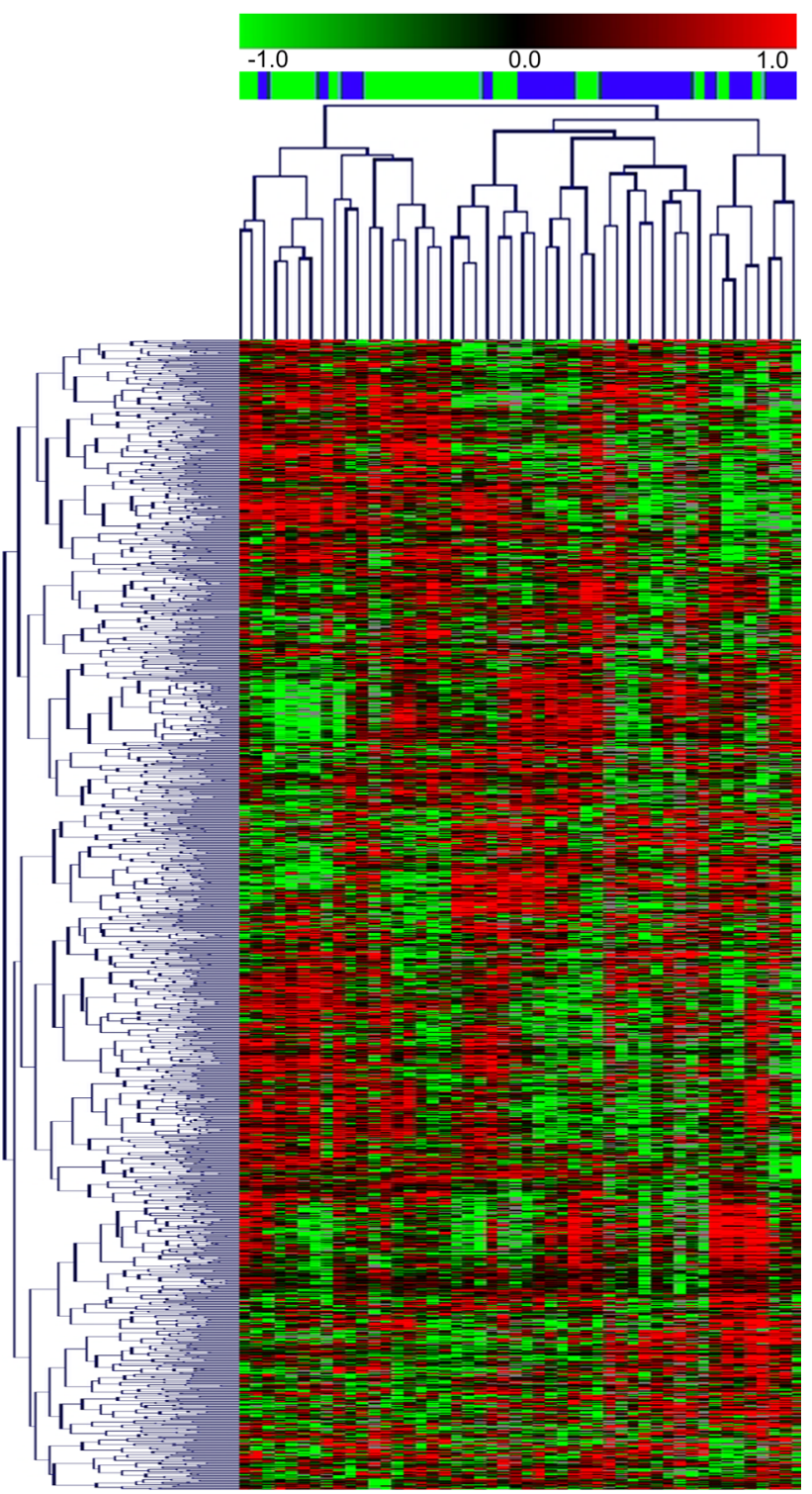

Fig. 3 Unsupervised hierarchical cluster analysis based on 1,346 overlapping genes from an idependent, publically available dataset [14]. The Lynch syndrome-associated tumors cluster together

\section{Discussion}

Lynch syndrome represents a rare but distinctive cause of ovarian cancer. Knowledge about involved tumorigenic mechanisms, genotype-phenotype correlations and optimal treatment is limited and no data on gene expression profiles in Lynch syndrome-associated ovarian cancer are available. Whole-genome DASL-based gene expression profiling based on $18.6 \mathrm{k}$ genes identified 349 significantly deregulated genes with up-regulation of e.g. PTPRH, BIRC3, SHH and TNFRSF6B in Lynch syndrome tumors.
PTPRH is part of the protein tyrosine phosphatase family and has tumor suppressor as well as oncogenic functions. BIRC3 has negative regulatory effect of the NFK $\beta$ signaling pathway, is associated with increased resistance to apoptosis and has also been linked to chemotherapy resistance [26, 27]. $S H H$ is crucial in embryonic development and TNFRSF6B is a member of the tumor necrosis factor superfamily that mediates cell death. Sporadic ovarian cancers on the other hand show up-regulation of SHCl, that acts down-stream of TP53 and is involved in cell migration and angiogenesis, and FSCNI that has been linked to invasive and metastatic potential in epithelial ovarian cancer [28]. Gene ontology analysis in Lynch syndrome tumors suggested involvement of genes related to cell growth, proliferation and cell death. The enrichment of cell growth and proliferation processes in Lynch syndrome ovarian cancers could potentially be linked to the predisposition for endometrioid tumors, which are typically low-grade tumors with low proliferation rates [13].

When the impact of heredity was analyzed within the different histopathologic subtypes, separate clustering was observed for endometrioid tumors and serous tumors (Fig. 2). These findings are based on small sample sets and need to be validated for further application. The lack of clustering within the clear cell cancer subset could potentially reflect a strong histology-related signature that overrules a potentially weaker hereditary signal, which is in line with distinct genetic alterations and clinical behavior in clear cell tumors [13, 29]. However, the finding of a stable genetic profile in Lynch syndrome-associated ovarian cancer is in line with previous studies on the impact from MMR deficiency for prognosis and prediction [4, 7, 8]. Clustering between Lynch syndrome tumors and sporadic tumors was achieved also when an independent, publically available data set was applied to our tumors (Fig. 3) [14]. In line with the observations by Tothill et al. [14] sub-clusters containing low-grade serous tumors and endometrioid tumors were identified, which may indicate distinct profiles also in these subtypes (data not shown).

The MAPK/ERK (MEK) signaling pathway is central in tumorigenesis and mutational activation has been suggested to have prognostic implications in ovarian cancer [30-34]. Mutations in KRAS and BRAF, which may activate the mTOR/PI3K/AKT pathway, are common in lowgrade ovarian cancers $(60 \%)$ but rare in high-grade cancers [35]. Up-regulation of the mTOR pathway has been linked to poor prognosis, potentially through increased resistance to chemotherapeutic drugs such as paclitaxel and cisplatin in sporadic ovarian cancer [23, 36, 37]. Upregulation of both mTOR and MEK signaling has been demonstrated in Lynch syndrome-associated colorectal cancer, and Niskakoski et al. recently reported frequent mutations in PIK3CA and absence of KRAS and BRAF mutations in 


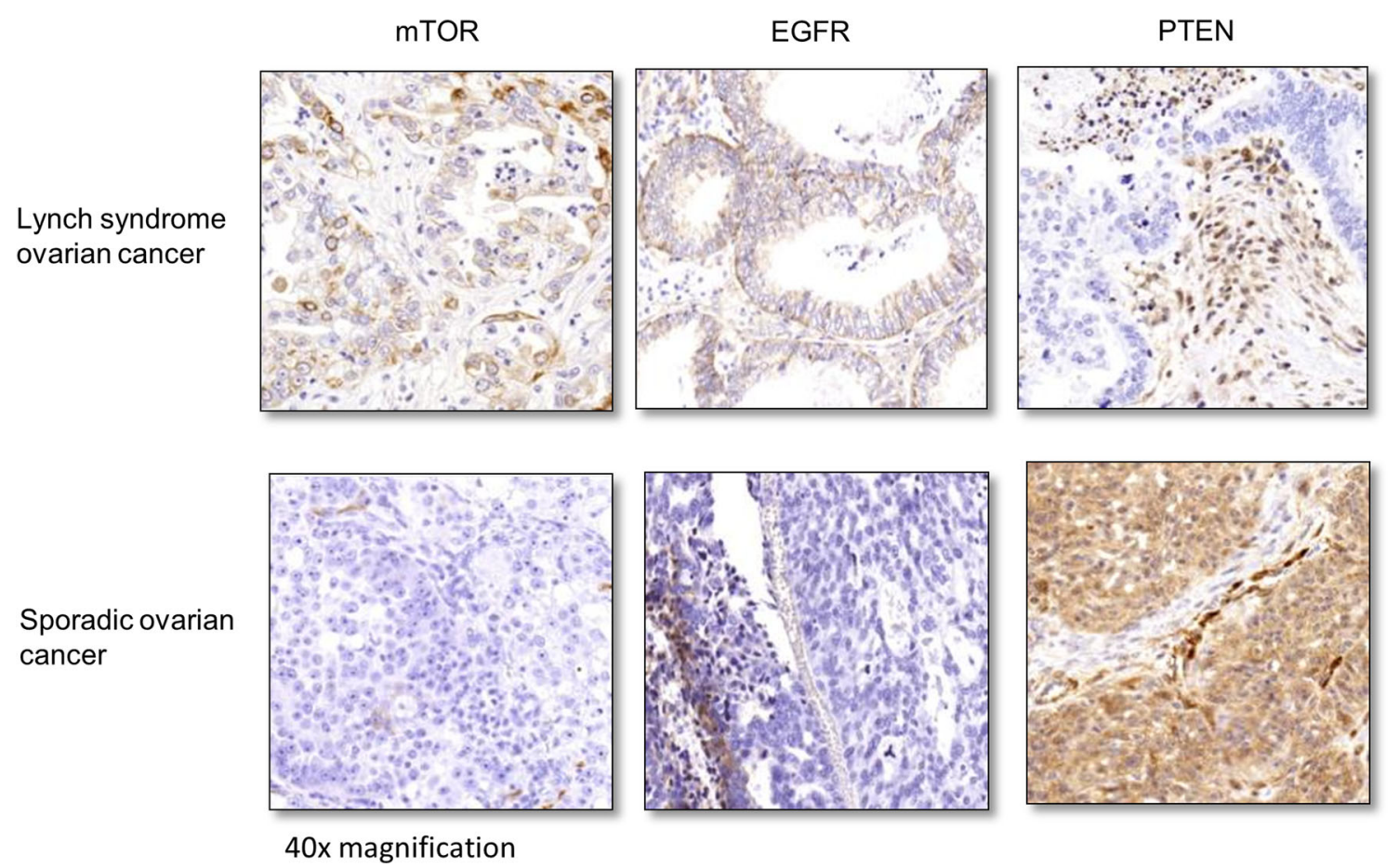

Fig. 4 Immunohistochemical stainings for p-mTOR, EGFR and PTEN in $\times 40$ magnification with Lynch syndrome-associated tumors presented on the top row and sporadic tumors on the bottom row. The left and middle columns show positive (top row) and negative (bottom row) p-mTOR and EGFR expression in tumor cells respectively. The right column shows negative PTEN expression in tumor cells but retained staining in surrounding tissue (top row) and positive PTEN expression in tumor cells and surrounding tissue (bottom row) ovarian cancers linked to Lynch syndrome [38, 39]. Immunohistochemical staining for mTOR, EGFR and PTEN was motivated by these markers being key targets that have also been shown to be up-regulated in Lynch syndrome-associated colorectal cancer. Though frequent deregulation was observed, significant differences were not demonstrated, which could relate to other mechanisms of activation as well as alternative target proteins.

In summary, the gene expression profiles in Lynch syndrome-associated and sporadic ovarian cancers showed stable and reproducible differences with 349 significantly deregulated genes, which were primarily related to cellular growth, proliferation and cell death. Our findings point to differences in tumorigenesis and suggest that targets in the deregulated pathways may be relevant for diagnostic and therapeutic intervention in ovarian cancer linked to Lynch syndrome.

Acknowledgments The study was conducted at the SCIBLU Genomics Facility at Lund University, Lund, Sweden. We would like to acknowledge Anna Karlsson for generous assistance with the DASL assay. Financial support was granted from a governmental funding of clinical research within the National Health Services (ALF), the Swedish Cancer Fund, the Swedish Research Council, the Nilsson Cancer Foundation and the Kamprad Cancer Foundation.

Conflict of interest The authors declare no interests of conflict.
Open Access This article is distributed under the terms of the Creative Commons Attribution License which permits any use, distribution, and reproduction in any medium, provided the original author(s) and the source are credited.

\section{References}

1. Malander S, Ridderheim M, Masback A, Loman N, Kristoffersson U, Olsson H, Nilbert M, Borg A (2004) One in 10 ovarian cancer patients carry germ line BRCA1 or BRCA2 mutations: results of a prospective study in Southern Sweden. Eur J Cancer 40(3):422-428

2. Rubin SC, Blackwood MA, Bandera C, Behbakht K, Benjamin I, Rebbeck TR, Boyd J (1998) BRCA1, BRCA2, and hereditary nonpolyposis colorectal cancer gene mutations in an unselected ovarian cancer population: relationship to family history and implications for genetic testing. Am J Obstet Gynecol 178(4):670-677

3. Malander S, Rambech E, Kristoffersson U, Halvarsson B, Ridderheim M, Borg A, Nilbert M (2006) The contribution of the hereditary nonpolyposis colorectal cancer syndrome to the development of ovarian cancer. Gynecol Oncol 101(2):238-243. doi:10.1016/j.ygyno.2005.10.029

4. Pal T, Permuth-Wey J, Kumar A, Sellers TA (2008) Systematic review and meta-analysis of ovarian cancers: estimation of microsatellite-high frequency and characterization of mismatch repair deficient tumor histology. Clin Cancer Res 14(21):6847-6854. doi:10.1158/1078-0432.CCR-08-1387 
5. Vasen HF, Stormorken A, Menko FH, Nagengast FM, Kleibeuker JH, Griffioen G, Taal BG, Moller P, Wijnen JT (2001) MSH2 mutation carriers are at higher risk of cancer than MLH1 mutation carriers: a study of hereditary nonpolyposis colorectal cancer families. J Clin Oncol 19(20):4074-4080

6. Grindedal EM, Renkonen-Sinisalo L, Vasen H, Evans G, Sala P, Blanco I, Gronwald J, Apold J, Eccles DM, Sanchez AA, Sampson J, Jarvinen HJ, Bertario L, Crawford GC, Stormorken AT, Maehle L, Moller P (2010) Survival in women with MMR mutations and ovarian cancer: a multicentre study in Lynch syndrome kindreds. J Med Genet 47(2):99-102. doi:10.1136/jmg. 2009.068130

7. Crijnen TE, Janssen-Heijnen ML, Gelderblom H, Morreau J, Nooij MA, Kenter GG, Vasen HF (2005) Survival of patients with ovarian cancer due to a mismatch repair defect. Fam Cancer 4(4):301-305. doi:10.1007/s10689-005-6573-2

8. Watson P, Vasen HF, Mecklin JP, Bernstein I, Aarnio M, Jarvinen HJ, Myrhoj T, Sunde L, Wijnen JT, Lynch HT (2008) The risk of extra-colonic, extra-endometrial cancer in the Lynch syndrome. Int J Cancer 123(2):444-449. doi:10.1002/ijc.23508

9. Aarnio M, Sankila R, Pukkala E, Salovaara R, Aaltonen LA, de la Chapelle A, Peltomaki P, Mecklin JP, Jarvinen HJ (1999) Cancer risk in mutation carriers of DNA-mismatch-repair genes. Int J Cancer 81(2):214-218. doi:10.1002/(SICI)1097-0215(19990412)81: $2<214$ :AID-IJC8>3.0.CO;2-L

10. Kurman RJ, Shih Ie M (2010) The origin and pathogenesis of epithelial ovarian cancer: a proposed unifying theory. Am J Surg Pathol 34(3):433-443. doi:10.1097/PAS.0b013e3181cf3d79

11. Singer G, Stohr R, Cope L, Dehari R, Hartmann A, Cao DF, Wang TL, Kurman RJ, Shih Ie M (2005) Patterns of p53 mutations separate ovarian serous borderline tumors and low- and high-grade carcinomas and provide support for a new model of ovarian carcinogenesis: a mutational analysis with immunohistochemical correlation. Am J Surg Pathol 29(2):218-224

12. Cho KR, Shih Ie M (2009) Ovarian cancer. Annu Rev Pathol 4:287-313. doi:10.1146/annurev.pathol.4.110807.092246

13. Kurman RJ, Shih Ie M (2008) Pathogenesis of ovarian cancer: lessons from morphology and molecular biology and their clinical implications. Int J Gynecol Pathol 27(2):151-160. doi:10.1097/ PGP.0b013e318161e4f5

14. Tothill RW, Tinker AV, George J, Brown R, Fox SB, Lade S, Johnson DS, Trivett MK, Etemadmoghadam D, Locandro B, Traficante N, Fereday S, Hung JA, Chiew YE, Haviv I, Gertig D, DeFazio A, Bowtell DD (2008) Novel molecular subtypes of serous and endometrioid ovarian cancer linked to clinical outcome. Clin Cancer Res 14(16):5198-5208. doi:10.1158/10780432.CCR-08-0196

15. Marquez RT, Baggerly KA, Patterson AP, Liu J, Broaddus R, Frumovitz M, Atkinson EN, Smith DI, Hartmann L, Fishman D, Berchuck A, Whitaker R, Gershenson DM, Mills GB, Bast RC Jr, $\mathrm{Lu} \mathrm{KH} \mathrm{(2005)} \mathrm{Patterns} \mathrm{of} \mathrm{gene} \mathrm{expression} \mathrm{in} \mathrm{different} \mathrm{histotypes}$ of epithelial ovarian cancer correlate with those in normal fallopian tube, endometrium, and colon. Clin Cancer Res 11(17):6116-6126. doi:10.1158/1078-0432.CCR-04-2509

16. Silverberg SG (2000) Histopathologic grading of ovarian carcinoma: a review and proposal. Int J Gynecol Pathol 19(1):7-15

17. Tavassoli FA, Devilee P (2003) Pathology and genetics of tumours of the breast and female genital organs. World Health Organization classification of tumours. IARC Press, Lyon

18. Zaino RJ, Kurman RJ, Diana KL, Morrow CP (1995) The utility of the revised International Federation of Gynecology and Obstetrics histologic grading of endometrial adenocarcinoma using a defined nuclear grading system. A Gynecologic Oncology Group study. Cancer 75(1):81-86

19. Ketabi Z, Bartuma K, Bernstein I, Malander S, Gronberg H, Bjorck E, Holck S, Nilbert M (2011) Ovarian cancer linked to Lynch syndrome typically presents as early-onset, non-serous epithelial tumors. Gynecol Oncol. doi:10.1016/j.ygyno.2011.02.010

20. Saeed AI, Sharov V, White J, Li J, Liang W, Bhagabati N, Braisted J, Klapa M, Currier T, Thiagarajan M, Sturn A, Snuffin M, Rezantsev A, Popov D, Ryltsov A, Kostukovich E, Borisovsky I, Liu Z, Vinsavich A, Trush V, Quackenbush J (2003) TM4: a free, open-source system for microarray data management and analysis. Biotechniques 34(2):374-378

21. Tusher VG, Tibshirani R, Chu G (2001) Significance analysis of microarrays applied to the ionizing radiation response. Proc Natl Acad Sci USA 98(9):5116-5121. doi:10.1073/pnas.091062498

22. Edgar R, Domrachev M, Lash AE (2002) Gene Expression Omnibus: NCBI gene expression and hybridization array data repository. Nucleic Acids Res 30(1):207-210

23. Altomare DA, Wang HQ, Skele KL, De Rienzo A, Klein-Szanto AJ, Godwin AK, Testa JR (2004) AKT and mTOR phosphorylation is frequently detected in ovarian cancer and can be targeted to disrupt ovarian tumor cell growth. Oncogene 23(34):5853-5857. doi:10. 1038/sj.onc. 1207721

24. Kurose K, Zhou XP, Araki T, Cannistra SA, Maher ER, Eng C (2001) Frequent loss of PTEN expression is linked to elevated phosphorylated Akt levels, but not associated with p27 and cyclin D1 expression, in primary epithelial ovarian carcinomas. Am J Pathol 158(6):2097-2106. doi:10.1016/S0002-9440(10)64681-0

25. Skirnisdottir I, Seidal T, Sorbe B (2004) A new prognostic model comprising p53, EGFR, and tumor grade in early stage epithelial ovarian carcinoma and avoiding the problem of inaccurate surgical staging. Int J Gynecol Cancer 14(2):259-270. doi:10.1111/j. 1048-891X.2004.014209.x

26. Julien SG, Dube N, Hardy S, Tremblay ML (2011) Inside the human cancer tyrosine phosphatome. Nat Rev Cancer 11(1):35-49. doi:10.1038/nrc2980

27. Rossi D, Fangazio M, Rasi S, Vaisitti T, Monti S, Cresta S, Chiaretti S, Del Giudice I, Fabbri G, Bruscaggin A, Spina V, Deambrogi C, Marinelli M, Fama R, Greco M, Daniele G, Forconi F, Gattei V, Bertoni F, Deaglio S, Pasqualucci L, Guarini A, Dalla-Favera R, Foa R, Gaidano G (2012) Disruption of BIRC3 associates with fludarabine chemorefractoriness in TP53 wildtype chronic lymphocytic leukemia. Blood 119(12):2854-2862. doi:10.1182/blood-2011-12-395673

28. Hanker LC, Karn T, Holtrich U, Graeser M, Becker S, Reinhard J, Ruckhaberle E, Gevensleben H, Rody A (2013) Prognostic impact of fascin-1 (FSCN1) in epithelial ovarian cancer. Anticancer Res 33(2):371-377

29. Tan DS, Iravani M, McCluggage WG, Lambros MB, Milanezi F, Mackay A, Gourley C, Geyer FC, Vatcheva R, Millar J, Thomas K, Natrajan R, Savage K, Fenwick K, Williams A, Jameson C, El-Bahrawy M, Gore ME, Gabra H, Kaye SB, Ashworth A, ReisFilho JS (2011) Genomic analysis reveals the molecular heterogeneity of ovarian clear cell carcinomas. Clin Cancer Res 17(6):1521-1534. doi:10.1158/1078-0432.CCR-10-1688

30. Singer G, Oldt R 3rd, Cohen Y, Wang BG, Sidransky D, Kurman RJ, Shih Ie M (2003) Mutations in BRAF and KRAS characterize the development of low-grade ovarian serous carcinoma. J Natl Cancer Inst 95(6):484-486

31. Hsu CY, Bristow R, Cha MS, Wang BG, Ho CL, Kurman RJ, Wang TL, Shih Ie M (2004) Characterization of active mitogenactivated protein kinase in ovarian serous carcinomas. Clin Cancer Res 10(19):6432-6436. doi:10.1158/1078-0432.CCR-040893

32. Sivaraman VS, Wang H, Nuovo GJ, Malbon CC (1997) Hyperexpression of mitogen-activated protein kinase in human breast cancer. J Clin Invest 99(7):1478-1483. doi:10.1172/JCI119309

33. Allen LF, Sebolt-Leopold J, Meyer MB (2003) CI-1040 (PD184352), a targeted signal transduction inhibitor of MEK (MAPKK). Semin Oncol 30(5 Suppl 16):105-116 
34. Peyssonnaux C, Eychene A (2001) The Raf/MEK/ERK pathway: new concepts of activation. Biol Cell 93(1-2):53-62

35. The Cancer Genome Atalas Network (2011) Integrated genomic analyses of ovarian carcinoma. Nature 474(7353):609-615. doi:10.1038/nature 10166

36. Bjornsti MA, Houghton PJ (2004) The TOR pathway: a target for cancer therapy. Nat Rev Cancer 4(5):335-348. doi:10.1038/ nrc1362

37. Mamane Y, Petroulakis E, LeBacquer O, Sonenberg N (2006) mTOR, translation initiation and cancer. Oncogene 25(48):64166422. doi:10.1038/sj.onc. 1209888
38. Ekstrand AI, Jonsson M, Lindblom A, Borg A, Nilbert M (2010) Frequent alterations of the $\mathrm{PI} 3 \mathrm{~K} / \mathrm{AKT} / \mathrm{mTOR}$ pathways in hereditary nonpolyposis colorectal cancer. Fam Cancer 9(2):125-129. doi:10.1007/s10689-009-9293-1

39. Niskakoski A, Kaur S, Renkonen-Sinisalo L, Lassus H, Järvinen HJ, Mecklin JP, Bützow R, Peltomäki P. Distinct molecular profiles in Lynch syndrome-associated and sporadic ovarian carcinomas. Int J Cancer. doi:10.1002/ijc.28287 